Research Article

\title{
Experimental antibacterial activity of selective cyclooxygenase antagonist
}

\author{
Hayder M. Al-kuraishy ${ }^{1}$, Ali I. Algareeb ${ }^{2}$, Salah A. Al-windy ${ }^{3}$
}

\begin{abstract}
${ }^{1}$ Department of Pharmacology and Medicine College of Medicine, Al-Mustansiriya University, P.O. Box 14132, Baghdad, Iraq ${ }^{2}$ Department of Pharmacology College of Medicine, AlMustansiriya University, P.O. Box 14132, Baghdad, Iraq ${ }^{3}$ Department of Biology, College of Sciences, Baghdad University, Iraq
\end{abstract}

Received: 17 April 2013 Accepted: 10 May 2013

\section{*Correspondence to: \\ Dr. Hayder M. Al-kuraishy, Email: \\ hayder_m36@yahoo.com}

(C) 2013 Al-kuraishy HM et al. This is an open-access article distributed under the terms of the Creative Commons Attribution License, which permits unrestricted use, distribution, and reproduction in any medium, provided the original work is properly cited.

\begin{abstract}
Background: From the history of the development of pharmaceutical compounds it is evident that any drug may have the possibility of possessing diverse functions and thus may have useful activity in completely different fields of medicine and different studies showed that newer antimicrobials have revealed antimicrobial action involved in the management of diseases of noninfectious etiology. This study was done to determine in vitro antibacterial activity of selected selective cyclooxygenase-2 inhibitor.

Methods: Twenty two strains of gram positive and gram negative bacteria, which were isolated from skin and urinary tract infected patient. These bacteria were being cultured on specific optimal growth media. The antibacterial activity of selective COX-2 (meloxicam, celecoxib, valdecoxib and nimesulide). Inhibitors determined by measuring zone of inhibition and minimal inhibitory concentration (MIC).

Results: Results showed that MIC of celecoxib and meloxicam in $\mu \mathrm{g} / \mathrm{ml}$ was ranged from $5-80 \mu \mathrm{g} / \mathrm{ml}$ on selected bacteria compared with negative control distilled water (D.W) ,valdecoxib was $80-160 \mu \mathrm{g} / \mathrm{ml}$, while and nimesulide was ranged from 5-40 $\mu \mathrm{g} / \mathrm{ml}$.All the selected bacteria were showed sensitivity for all coxib used in this experimental study except Pseudomonas aeruginosa which showed resistant to meloxicam and valdecoxib, Klebsiella pneumoniae resist to nimesulide while Staphylococcus aureus was resist to valdecoxib. The smaller zone of inhibition showed by valdecoxib and celecoxib which was $3 \mathrm{~mm}$ against Klebsiella pneumoniae, while the larger zone of inhibition showed by nimesulide which was 26mm against Escherichia coli.

Conclusions: In conclusion selective cyclooxygenase (cox-2) inhibitor possesses antibacterial activity this is especially for nimesulide and little by valdecoxib. Escherichia coli are sensitive bacteria to all coxib. Consequently; coxib may be regarded as anti-inflammatory and antibacterial agent especially for urinary tract infection where Escherichia coli are the major causative organism.
\end{abstract}

Keywords: Antibacterial, Cyclooxygenase-2 inhibitor, Zone of inhibition

\section{INTRODUCTION}

The symposium of antibiotics and antibacterial chemotherapy is becoming more limited in spite of the fact that they exist in large numbers, the reason behind such a rapid turn down in the antibiotics is mainly attributed to the emergence of drug resistant bacteria, which render even some of the most broad spectrum antibiotics unsuccessful. ${ }^{1}$ Moreover, the toxic side effects produced by antibiotics reducing their demand and remarkable antimicrobial action is present in several compounds, ${ }^{2}$ belonging to various pharmacological categories, such as the antihistamines, ${ }^{3}$ tranquilizers ${ }^{4}$ the antihypertensive ${ }^{5}$ the antipsychotics ${ }^{6}$ and the antiinflammatory agents. ${ }^{7}$

Such compounds, having antimicrobial properties in addition to their original pharmacological actions, have been named as non-antibiotics. ${ }^{8,9}$ From the history of the development of pharmaceutical compounds it is evident that any drug may have the possibility of possessing diverse functions and thus may have useful activity in completely different fields of medicine ${ }^{10}$ and different studies showed that newer antimicrobials have revealed 
antimicrobial action involved in the management of diseases of non-infectious etiology. Non-steroidal antiinflammatory drugs produce their analgesic and antiinflammatory pharmacological effect by inhibiting the enzyme called cyclooxygenase $(\mathrm{COX}) .{ }^{11}$ Cyclooxygenase converts arachidonic acid found in cell membrane to prostacyclin, thromboxanes and various prostaglandins, each with its own effect on cell function and physiology. ${ }^{12}$ Two isoforms of COX have been identified, COX-1 is expressed constitutively in most tissues as maintenance protein and mediates physiological functions such as gastric mucosal cytoprotection and platelet aggregation and COX-2 however, is expressed only in certain tissues such as the kidney, brain and pancreatic islet cells ${ }^{13}$ and not found in most other tissues but is induced in response to cytokines and growth factors in inflammatory conditions. ${ }^{14}$ One of the serious drawbacks of NSAID is gastrointestinal irritation and ulceration, a side effect attributed to COX-1 inhibition. Therefore; COX-2specific inhibitors have been developed primarily as anti-inflammatory agents ${ }^{15}$ and they are better tolerated than non-specific NSAID with a comparable desired clinical effect; however, their toxic effect on renal function are essentially similar.

Search for anti-microbial action among the non-steroidal anti-inflammatory drugs, showed that diclofenac sodium exhibited significant potential antibacterial activity against both Gram-positive and Gram-negative bacteria. ${ }^{16}$ Diclofenac at concentration of $1.5-3.0 \mathrm{mg} / \mathrm{gm}$ bodyweight of Swiss strain of white mice could protect these animals when challenged with Salmonella typhimurium NCTC $74,{ }^{17}$ and demonstrated significant clearance of the pathogenic bacteria from liver and spleen. ${ }^{18,19}$

The aim of present study is to evaluate the antibacterial activity of selective cox-2 inhibitors like celecoxib; valdecoxib; meloxicam and nimesulide on selected Gram-positive and Gram-negative bacteria.

\section{METHODS}

This study was carried out in Department of Pharmacology, College of Medicine, Al-mustansiriya University, Baghdad - Iraq, 2012. It is approved by scientific jury of Department of Pharmacology, and licensed by board of medical college.

A total of 22 clinical isolate were analyzed .Out of these 10 samples were of UTI and 12 from skin infection .Pus and urine samples were collected from Al-Yarmouk teaching hospital using standard protocol of sample collection. These bacteria inoculated on blood and Maconky agar. Bacterial cultures were tested against selective cyclo-oxygenase inhibitors celecoxib, meloxicam, valdecoxib and nimesulide by agar well diffusion and tube dilution method. ${ }^{20,21} 10 \mathrm{mg} / \mathrm{ml}$ stock solution of each drug was made in sterile distilled water. Then serial dilution of concentration (0) control, $5 \mu \mathrm{g} / \mathrm{ml}$, $10 \mu \mathrm{g} / \mathrm{ml}, 20 \mu \mathrm{g} / \mathrm{ml}, 40 \mu \mathrm{g} / \mathrm{ml}, 80 \mu \mathrm{g} / \mathrm{ml}, 160 \mu \mathrm{g} / \mathrm{ml}$ were done. Then the Agar plates were incubated for 24 hours at $37^{\circ} \mathrm{C}$.

\section{Tube Dilution Method}

Serial dilutions of the coxib were made in Muller Hinton broth which was inoculated with a standardized number of organisms and incubated for 24 hours. The lowest concentration of drug that preventing the turbidity is considered to be the minimal inhibitory concentration (MIC).

\section{Agar Well Diffusion Methods}

Wells in the Muller Hinton Agar plates were made by the help of $6 \mathrm{~mm}$ borer. The culture was swabbed homogeneously across plates and the known concentration of the drug to be tested was added in the well $(5 \mu \mathrm{g} / \mathrm{ml}, 10 \mu \mathrm{g} / \mathrm{ml}, 20 \mu \mathrm{g} / \mathrm{ml}, 40 \mu \mathrm{g} / \mathrm{ml}, 80 \mu \mathrm{g} / \mathrm{ml}$, and $160 \mu \mathrm{g} / \mathrm{ml}$ ). If the drug is effective against bacteria at a certain concentration, no colonies will grow when the concentration in the agar is greater than or equal to the effective concentration, this is the zone of inhibition. Consequence, the size of the zone of inhibition is a measure of the compound's efficacy; the larger the clear area around the well, the more effective compound. The antibacterial activity was estimated based on size of inhibition zone formed around the well-seeded agar plates and inhibition of growth in percentage was determined based on the average diameter of colony on growth medium to their respective control. ${ }^{22}$

Drugs were obtained from private pharmaceutical company Ltd (Ajanta pharma limited, Ajanta House, clarkopkandivil (cw) Mumbai 4000, India).

\section{RESULTS}

Antibacterial property of selective cyclo-oxygenase-2 inhibitors were determined alongside different bacterial strains .The zone of inhibition of selective cyclooxygenase inhibitors on the selected bacterial strains are presented in table 1 .

Meloxicam showed inhibitory effects on all selected bacteria except of pseudomonas aeureginosa, celecoxib produced inhibition zone on all selected bacteria and valdecoxib produced minimal antibacterial effects on Klebsiella pneumoniae and no effects on staphylococcus aureus and pseudomonas aeureginosa, nimesulide produced greater zone of inhibition $26 \mathrm{~mm}$ and valdecoxib as celecoxib produced lesser zone of inhibition $3 \mathrm{~mm}$ regarding Escherichia coli as sensitive bacteria for all type of selective cyclo-oxygenase inhibitors figure 1 . 
Table 1: In vitro antibacterial activity of selective COX-2 inhibitor on different bacterial strain.

\begin{tabular}{|lllllll|}
\hline \multirow{2}{*}{ Bacterial type } & \multicolumn{5}{c|}{ Zone of inhibition (mm) } \\
\cline { 2 - 6 } & meloxicam & celecoxib & valdecoxib & nimesulide & control \\
\hline - $\quad$ Staph. aureus & 15 & 15 & 0 & 6 & 0 \\
\hline - & Escherichia coli & 18 & 4 & 12 & 26 & 2 \\
\hline - & Pseudomonas aeruginosa & 0 & 18 & 0 & 15 & 0 \\
\hline - $\quad$ Klebsiella pneumoniae & 6 & 3 & 3 & 0 & 1 \\
\hline
\end{tabular}

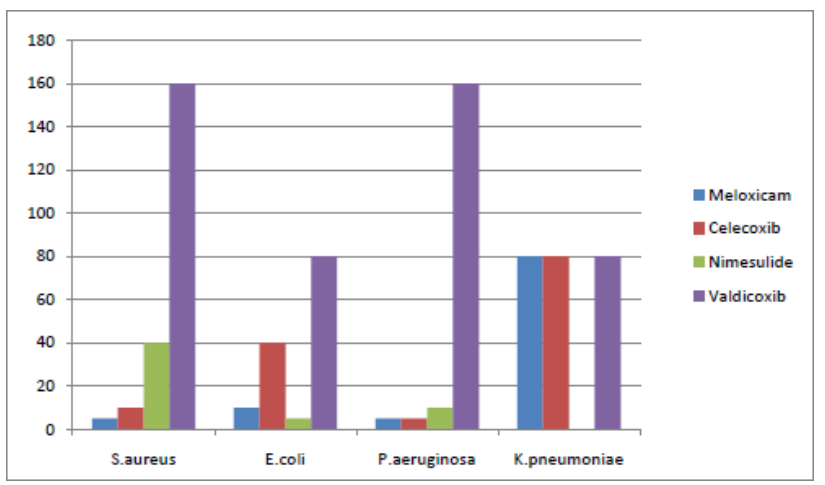

Figure 1: Minimal inhibitory concentration (MIC) of selective COX-2 inhibitor.

For determining the kinetic effects of these coxib against Escherichia coli (regarding it as sensitive bacteria for all type of selective cyclo-oxygenase inhibitors); colony forming unit (CFU) count of strain was $3 \times 10^{8}$ at zero time with subsequent addition of drug at sequential concentration; the CFU measured each two hours they were $4 \times 10^{6}, 3 \times 10^{5}$ and $2 \times 10^{4}$ after $2,4,6$ hours correspondingly (Figure 2 ).

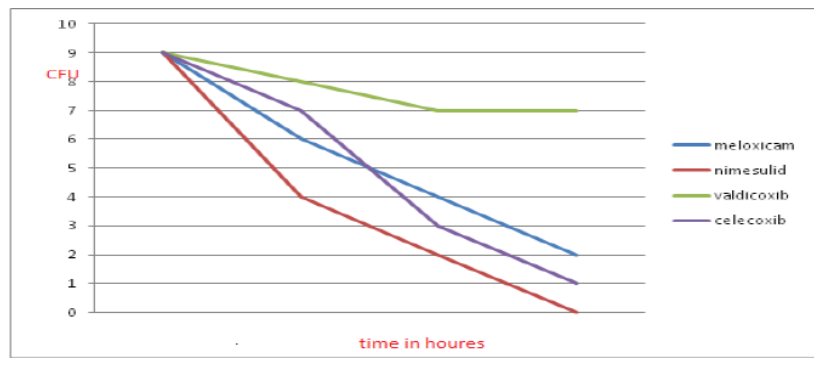

Figure 2: Kinetic and sequential effects of selective cyclo-oxygenase inhibitors against Escherichia coli growth.

\section{DISCUSSION}

The present study demonstrated effective antibacterial action of coxib in comparison with negative control (distilled water), nimesulide produced greater zone of inhibition against Escherichia coli and no effect against Klebsiella pneumonia while nimesulide showed significant antibacterial effects. From sequential coxib addition, results showed that all coxib are bactericidal with the exception of valdecoxib which fashioned as bacteriostatic effects rather than bactericidal regarding the bacterial growth per/ $\mathrm{ml}$ in each two hours because bactericidal effects (progressive decreasing in bacterial colony number/per time) while bacteriostatic effects (non-progressive in bacterial colony number/per time). ${ }^{23}$

The use of NSAID has been up evaluated not alter host response to infection. ${ }^{24-27}$ Previous study by Alem and Douglas (2004) in one experimental model ,viability assays were accomplish on both growing and fully matured biofilm to investigate the effects of aspirin, diclofenac and other NSAID on biofilm formation, accordingly this study showed that diclofenac, aspirin had maximum inhibitory effects with aspirin up to $95 \%$ inhibition, while celecoxib and ibuprofen also inhibit the bacterial biofilm but to a lesser extent. ${ }^{28}$ Moreover; coxib act by blocking prostaglandin synthesis through inhibition of cox- 2 enzyme in view of the fact that the lipoxygenase and cyclooxygenase pathway have the same precursor (arachidonic acid), inhibiting the metabolism of arachidonic acid via the cyclooxygenase pathway would enhance the lipoxygenase pathway, consequently; increasing of inflammatory leukotrienes. ${ }^{29}$ Leukotriene (LTB4) stimulate B-lymphocyte through T-lymphocyte, while, Leukotriene LTB4 and LTD4 increasing expression of IL-1, so coxib indirectly induce humoral and cellular immunity but these cytokines not measured in this study. ${ }^{30}$

The mechanism of antibacterial activity of the coxib was not well understood but in this study coxib have dual bacteriostatic and bactericidal effects, these results supported by Annduri 2008 in a trail of experimental antimicrobial activity of diclofenac sodium, showed that diclofenac possessed significant antimicrobial properties against salmonella typhimurium. The antibacterial action of diclofenac was found to be via inhibition of bacterial DNA which was demonstrated using $2 \mu \mathrm{Ci}(3 \mathrm{H})$ deoxythymidine uptake. ${ }^{31}$ On contrary Steven 2009 
incriminate the coxib as predisposing factor for bacterial infection due to inhibition of prostaglandin mediated granulocyte function, but coxib in previous showed it increase lipoxygenase pathway so elevate LTB4, LTD4 and cytokine expression so increasing in vivo bacterial clearance but toxic dose of most NSAID decrease the bacterial clearance ${ }^{32}$ unfortunately leukotrienes and prostaglandin levels were not measured in this study.

Moreover; inflammation promote bacterial growth because the inflammation lead to fluid build up in the area of injury due to increasing in the vascular permeability leading to limited to oedema which may actually support bacterial growth and causing tissue damage that provide a good media and nutrient for bacteria. ${ }^{33}$ Therefore; coxib inhibiting bacterial growth via inhibition of inflammatory process. ${ }^{34}$

Additionally cox-1 and cox-2 have critical but contrasting effects on host immune response to infection possibly mediated via altered production of prostaglandin (PG) and Leukotriene (LT) following infection, so deficiency of cox-1 result in enhanced inflammatory response and earlier release of pro-inflammatory cytokines, in contrast deficiency of cox-2 isoform results in reduction in inflammation and cytokine release. ${ }^{35}$

Proposed for that reason; coxib regarded as safe agent in treating bacterial infection than nonselective cox inhibitors. It was pragmatic by Anurup et al (2010) study the agents with two or more benzene ring possess strong antimicrobial activity like phenothiazine and tricycle antidepressant. ${ }^{36}$ As a result coxib has two benzene ring this per se might explain their antibacterial activity. ${ }^{37}$

Furthermore; celecoxib and meloxicam are potent COX-2 inhibitors that have been shown formerly to interact with the same binding site of the COX-2 enzyme in the submicromolar range, even so, celecoxib possessed antibacterial activity against Francisellatularensis and that the MIC of celecoxib for Francisellatularensisis (32 $\mu \mathrm{g} / \mathrm{ml}$ )which is much higher than was reported for COX$2(0.21 \mathrm{~g} / \mathrm{ml}))^{38}$ These findings advocate that the antimicrobial activity of celecoxib is independent of the structural features that dictate its binding to COX-2.

Accordingly; we assume that the supposed bacterial target of celecoxib for sensitive bacteria is structurally dissimilar from the COX-2 enzyme. Moreover; coxib independent action related to inhibition of cellular enzymes and antiapoptotic effects on vital organs and induction of apoptosis in malignant cells ,celecoxib has been reported to possess inhibitory activities against other mammalian enzymes, including phosphoinositidedependent kinase-1, carbonic anhydrase, sarcoplasmic/endoplasmic reticulum calcium ATPase, and COX $-1 .^{39}$ These mammalian enzymes may serve as leads to identify the structurally similar bacterial proteins, one of which may be the hypothetical antibacterial target of celecoxib in bacteria.
From all these previous studies we can conclude that coxib produced diversity of effects on host and microorganism regarding the antibacterial activity, hence; regarding host-microorganism relationship, coxib is regarded as harmful agent for bacteria and marginally not hazardous for host effects.

\section{Funding: None}

Conflict of interest: None declared

Ethical approval: The study was approved by scientific jury of Department of Pharmacology, and licensed by board of medical college.

\section{REFERENCES}

1. Dastidar SG, Saha PK, Sanyamat B and Chakrabarty A. Antibacterial activities of ambodryl and bendadryl. J Appl Bact 1976;41:209-14.

2. Chattopadhyay D, Dastidar S and Chakrabarty A. Anti-microbial property of methdilazine and its synergism with antibiotics and some chemotherapeutic agents. Arzneim Forsch1988;38:869-72.

3. Roy K and Chakrabarty A. Anti-bacterial activities of anti-histamine triprolidine hydrochloride (actidil) and cross-resistances to antibiotics developed by experimentally derived mutants resistant to this drug. Indian J Med Microbiol 1994;12:9-18.

4. Dastidar S, Jairaj J, Mookerjee M and Chakrabarty A. Studieson anti-microbial effect of the antihistaminic phenothiazine trimeprazine tartrate. Acta Microbiol Immun Hung 1997;44:241-7.

5. Molna J, Mandi Y and Kiraly J. Anti-bacterial effect of some phenothiazine compounds and the Rfactor elimination by chlorpromazine. Acta Microbiol Acad Sci Hung 1996;23:45-54.

6. Kristiansen J. Experiments to illustrate the effect of chlorpromazine on the permeability of the bacterial cell wall. Acta Path Microbiol Scand Sect B 1979;87:317-9.

7. Kristiansen $\mathbf{J}$ and Mortensen I. Anti-bacterial effect of four phenothiazines. Pharmacol Toxicol 1987;60:100-3.

8. Dastidar S, Chaudhuri A, Annadurai S, Ray S, Mookerjee $\mathrm{M}$ and Chakrabarty A. In vitro and in vivo anti-microbial action of fluphenazine. J Chemother 1995;7:201-6.

9. Mondal U, Niyogi S, Chakrabarty A. Anti-bacterial property of methyl-DOPA and development of antibiotic cross-resistances in m-DOPA mutants. Indian J Med Res1986;84:142-7.

10. Manna K and Dastidar S. The anti-hypertensive drug propranolol hydrochloride (carditap): its antibacterial property.. Proceedings of National Congress of IAMM (Image India, Calcutta), 2001;984:137-41.

11. Garcia-Rodriguez J. Invitro activity of non steroidal anti-inflammatory agents. Eur J Clin Microbial Infec Dis1999; 15:418-20. 
12. Komhoff $\mathrm{M}$, Wang $\mathrm{J}$, Cheng $\mathrm{H}$, et al. Cyclooxygenase-2-selective inhibitors impair glomerulogenesis and renal cortical development. Kidney Int 2000; 57:414-22.

13. Van J, Bakhle Y andBotting R. Cyclooxygenases 1 and 2. Ann Rev Pharmacol Toxicol 1998; 38:97-9.

14. Kurumbail R, Stewens A, Gierse J, McDonald J, Stegeman RA, Pak J, et al. Structural basis for selective inhibition of cyclooxygenase- 2 by antiinflammatory agents. Nature 1996; 384:644-8.

15. Pairet $\mathrm{M}$ and van Ryn J. Experimental models used to investigate the differential inhibition of cyclooxigenase-1 andcyclooxygenase- 2 by nonsteroidal anti-inflammatory drugs. Inflamm Res 1998;47:93-101.

16. Annadurai S, Basu S, Ray S, Dastidar S and, Chakrabarty A. Anti-bacterial activity of the antiinflammatory agent diclofenac sodium. Indian J Exp Biol 1998;36:86-90.

17. Munoz-Criado S, Munoz-Bellido $\mathrm{J}$ and GarciaRodriguez J. Invitro activity of non steroidal antiinflammatory agents, phenothiazines and antidepressants against Brucellaspecies. Eur J Clin Microbial Infec Dis 1996;15:418-20.

18. Kurumbail RG, Stewens AM, Gierse JK, McDonald JJ, Stegeman RA, Pak JY, et al. Structural basis for selective inhibition of cyclooxygenase- 2 by antiinflammatory agents. Nature2002;384:644-81

19. Annadurai S, Basu S, Ray S, Dastidar S and Chakrabarty A. Anti-bacterial activity of the antiinflammatory agent diclofenac sodium. Indian J Exp Biol 1998;36:86-90.

20. Barrow $G$ and Feltham R. Cowan and Steel for identification of medical bacteria. (Cambridge University press, Cambridge, UK, 1993.

21. National Committee for Clinical Labrotory Standarded. Methode for dilution in antimicrobial Susceptibility Test. Approved Staandared. M2-A5 NCCLS, Villanova,PA1999.

22. Abu-El-Wahab ZH and El-sarrag MR. Derivative of phosphate shift base trasition and biological activity Spec Acta 2004;60:271-7.

23. Rainsford K. Profile and mechanism of gastrointestinal and other side effects of NSAID. AM J Med1999; 107:27-35.

24. CoruzziG, Menzzi A and Dobrilla G. Novel NSAID: What we have learned from animal studies. Curr Drug Target inflamm Allergy 2009;3:43-61.

25. Donneelly M. Review article: COX-2 inhibitor a new generation of safer NSAID? Aliment Phamacol Ther 2007;11:227-30.

26. Crofford LJ. Basic biology and clinical application of specific COX-2 inhibitor. Artharitis Rheum 2000;43:4-13.

27. Payan D and Katzung B. Non-steroidal antiinflammatory drugs; nonopoid analgesics; drugs used in gout, In: Katzung BG (ed), Basic and clinical pharmacology, 6th ed. Appleton and Lange, USA 1995.

28. Alem M and Douglas L. Effects of aspirin and other nonsteroidal anti- inflammatory drugs on biofilms and planktonic cells of Candida albicans. Antimicrob Agents Chemother 2004;48:41-7.

29. Hecker M, Foegh $M$ and Ramwell P. The eicosanoids: prostaglandins, thromboxanes, leukotrienes and related compounds. In: Katzung BG (ed) Basic and clinical pharmacology, 6th ed. Appleton and Lange, USA pp. 1995; 290-304.

30. Helle M, Brakenhoff J, de Groot E and Aarden L. Interleukin-6 is involved in interleukin-1 induced activities. Eur J Immunol 2006;18:957-9.

31. Annaduri S, Basu S, Ray S, Dastidar S and Chakrabarty A. Antimicrobial activity of the antiinflammatory agent, diclofenac sodium. Indian J Exp Biol 2008;36:86-90.

32. Stevens D. Could nonsteroidal anti-inflammatory drugs (NSAIDs) enhance the progression of bacterial infections to toxic shock syndrome? Clin Infect Dis 2009;21:977-80.

33. Madigan M, Martinko J and ParterJ. Microbial growth control. In: Brock TD (ed), Brock biology of microorganisms. 9th ed. Prentice HillInc, USA2000.

34. Mycek M, Harvey $R$ and Champe P. Antiinflammatory drugs, In: Lippincott's illustrated reviews. 2nd ed Lippincott Williams and Wilkins, USA, pp. 2006; 401-20.

35. Michelle A, Carey J, Alyce B, John M, Robert L, et al. Contrasting effects of cyclooxygenase (cox-1) and $\operatorname{cox} 2$ deficiency on the host response to influenza A viral infection. $\mathrm{J}$ Immunol 2010;100:762-5.

36. Anurup M, Chanrima S, Aditya K, Jena R, et al. An investigation in vitro and vivo antimicrobial properties of the antidepressant amitriptyline hydrochloride. Brazillian Journal of microbiology 2010;41:635-42.

37. Schonthal A. Antitumor properties of dimethylcelecoxib, a derivative of celecoxib that does not inhibit cyclooxygenase-2: implications for glioma therapy. Neurosurg Focus 2006;20(4):33-5.

38. Santic M, R Asare, I Skrobonja, S. Jones Y. Acquisition of the vacuolar ATPase proton pump and phagosome acidification are essential for escape of Francisellatularens is into the macrophage cytosol. Infect Immun 2008;76:2671-7.

39. Schonthal A. Direct non-cyclooxygenase-2 targets of celecoxib and their potential relevance for cancer therapy. Br J Cancer 2009;97:1465-8.

doi:10.5455/2319-2003.ijbcp20130807

Cite this article as: Al-kuraishy HM, Algareeb AI, Al-windy SA. Experimental antibacterial activity of selective cyclooxygenase antagonist. Int J Basic Clin Pharmacol 2013;2:381-5. 